Review Article

\title{
Pathways for the Improvement of Construction Productivity: A Perspective on the Adoption of Advanced Techniques
}

\author{
Pejman Ghasemi Poor Sabet and Heap-Yih Chong \\ School of Design and Built Environment, Curtin University, Perth, Australia \\ Correspondence should be addressed to Heap-Yih Chong; heap-yih.chong@curtin.edu.au
}

Received 22 July 2019; Accepted 23 January 2020; Published 13 February 2020

Academic Editor: Pier Paolo Rossi

Copyright (c 2020 Pejman Ghasemi Poor Sabet and Heap-Yih Chong. This is an open access article distributed under the Creative Commons Attribution License, which permits unrestricted use, distribution, and reproduction in any medium, provided the original work is properly cited.

\begin{abstract}
Reinventing construction is the key to improving productivity. This reinvention refers to not only inventing advanced materials and equipment but also developing new operating systems for construction projects. Inadequate application of advanced techniques impedes the operating system. Furthermore, the capabilities of advanced techniques may not cover all the areas required to meet the expected productivity level. The implications of these advanced techniques need to be reinforced by a range of productive fundamentals that remain unclarified. Further, the pathways through which these fundamentals can be aligned with the implementation of advanced techniques remain under-researched. Hence, the objectives of this research are as follows: (1) to clarify how the selected and common advanced techniques applied in this paper influence construction productivity; (2) to determine the range of productivity fundamentals required to reinforce the implementation of the advanced techniques necessary to fulfil productivity expectations; and (3) to conceptualise the integration of these productivity fundamentals with the application of advanced techniques. A scoping review of 128 articles was used to identify which fundamentals can contribute to achieving performance targets once practising these new advanced techniques. The findings reveal a comprehensive range of productivity fundamentals that are able to reinforce new advanced techniques through different pathways of their applications.
\end{abstract}

\section{Introduction}

The construction industry is a major contributor to the gross domestic product (GDP) of a country's economy [1]. The issue of the decline of productivity in the construction industry [2] has been put in the spotlight due to failures to meet ever-changing performance expectations for half a century $[3,4]$. Therefore, there is a need to bring productivity out of this deadlocked state since the construction industry, directly and indirectly, impacts the economy [4] of both developing and developed countries. As the main aspects of performance, inefficiencies in time, cost, and quality in the Iron Triangle not only result in client dissatisfaction but also negatively impact the economy in a broader sense. In the United Kingdom (UK), a pioneer in the construction industry, this issue has caused the authorities to consider construction re-engineering. The construction sector needs an upgraded operating system to allow it to meet the expectation of productivity growth in compliance with the pillars of the Iron Triangle as the primary performance constraints. These constraints were later extended to five criteria, including time, cost, quality, scope, and risk [5]. Sabet and Chong [6] defined these criteria as time, cost, quality, stockholder satisfaction, and safety, the main aspects of construction performance. The question of how to manage these constraints challenges companies and authorities in the construction industry. New business models and upgraded construction management are required to eliminate the challenges associated with meeting expected construction performance [7]. An effective project operating system that is supported by technological innovation is at the heart of a better workflow [8]. Management considerations and the implementation of advanced techniques have not yet satisfied the requirements for performance achievement. Those measures need to be reinforced by a range of productivity fundamentals that can help to fulfil productivity 
objectives at different stages of a project. The question arises as to which fundamentals can supplement the capabilities of these advanced techniques.

Hence, this paper addresses a range of productivity fundamentals and clarifies how they play a vital role in meeting performance goals once the required advanced techniques have been implemented. The potential benefits may be useful to (a) developers of new techniques, who may use this study to establish upgraded technical concepts for the updated productivity criteria linked to project performance, and (b) practitioners who should consider these productivity fundamentals for the effective implementation of advanced techniques.

\section{Literature Review}

2.1. Productivity Requirements and Issues. The construction sector is a pillar of the gross domestic product (GDP) of a country. The income derived from the construction industry is a significant proportion of GDP, as are the indirect incomes that arise from marketing and operational services [9]. The inefficiencies arising from the construction sector not only result in client dissatisfaction but also impact the economy due to low productivity. Lack of an integrated management followed by fragmentation among the stockholders has been flagged as factors that reduce the construction productivity in conventional construction $[10,11]$.

Low construction productivity has always challenged stakeholders and clients. Force ([12], p. 10) stated that "clients need better value from their project, and companies need reasonable profits to assure their long-term future." Development of new strategies is an important task for researchers aiming to improve the industry. Implementation of new techniques and technologies in process development has been important in overcoming the challenge of low productivity. In this regard, fostering commitment between the parties involved in a project appears to be one of the important requirements of the process. Force [12] stated that embracing change has been identified as the key factor in successfully improving productivity in industry, but that the construction industry has been very resistant to change. According to [12], a series of fundamentals of the project process, such as committed leadership, focus on the customer's requirements, process and team integration, qualitydriven agenda, and commitment to the different stakeholders, are the radical changes required in the construction industry. These necessary changes are impossible without properly implementing new techniques and technology to increase innovation. Winch ([13], p. 268) stated that "the roles of the innovation infrastructure, innovation superstructure and systems integrator are the fundamentals of the successful establishment of innovation in the construction industry." Also, effective management of multicultural human resources at different levels at job sites is another consideration fundamental to project productivity and success $[14,15]$. Moreover, skilled benchmarking can play an important role in improving a construction project. According to the Task Force Report [12], practising these fundamentals together are the only way to successfully implement new techniques and technologies. Changali et al. [8] argue that fast-growing investment, requests for larger shares in megaprojects, and poor completion of megaprojects determine the need for new techniques and approaches that are consistent with the productivity expectations for future projects. They believe that a range of measurements made at three stages of a project, namely, concept and design; contract and procurement; and lastly execution, can remove potential weaknesses reducing productivity. Changali et al. [8] stated that slow decisionmaking and processes within an organisation can result from inaccurate and poor reporting from team members and stockholders. In fact, this shortcoming impedes communication between stakeholders and prevents prompt action within a project.

Lack of clear contracts is another reason for the productivity loss. In this case, the negotiations required to manage any conflicts as they arise are complicated and may have followed a lengthy dispute resolution process. As different roles and activities are defined at different layers within a project, suitable measures are required to network these roles and control activities to avoid any interference in planning and scheduling (resolution of the issue of fragmentation). Short-term planning and taking alternatives to reinforce planning and scheduling are important considerations to keep project progress on track. Further, a consistent management style is central to ensuring that staff contribute their highest capacities and competencies to a project. Inappropriate risk allocation has also been reported as a cause of inefficiencies; not involving stakeholders other than the contractor puts all the responsibility for the project on the contractor.

Previous studies have largely focused on determining the productivity indicators in construction projects from the perspective of value-creating approaches. Cost benefit analysis and return on investment (ROI) have been used evaluate the performance resulting from the implementation of new techniques and technologies. However, no prior research has considered a generic pathway or the interactions between productivity indicators and aspects of construction performance after the implementation of advanced techniques in projects. This paper discusses the pathways through which the new advanced techniques can impact different aspects of performance, and suggests a range of productivity fundamentals that can act as catalysts or reinforcers that contribute to the improvement of the operating system via the implementation of advanced techniques. This paper claims overall project performance to be the output of a function in which potential productivity fundamentals are aligned with the implementation of advanced techniques.

As the literature implies, the factors affecting construction productivity can be identified as delayed schedules, changed orders, materials mismanagement, unstable weather conditions, and human performance-related factors. Park [16] claimed that management considerations and environmental conditions play the determinant roles in estimating productivity in construction. Bassioni et al. [17] believed that identifying the indicators affecting productivity 
that interact with new techniques can result in successful productivity improvement. The following table categorises the factors threatening the productivity that have been identified in the literature. It may help developers of new techniques to consider the actions required to eliminate weaknesses in the establishment of future technologies and approaches.

Improved construction performance is the result of productivity improvement [6]. Force [12] observed the potential for productivity improvement by reducing capital costs, project duration, number of accidents, employee turnover, and staff productivity. Barbosa et al. [40] reported that poor construction performance may be due to fragmentation of stakeholders, contract mismanagement, and opaque marketplace. Therefore, a range of measurements of these strengths and weaknesses can contribute to assessing the overall project performance.

2.2. Debate on ROI. This debate has been raised due to risk of the loss of value of investments. A reasonable ratio of benefit to cost is expected from the ROI perspective. Time, cost, quality, safety, and stakeholder satisfaction are the pillars of ROI. Developing the range of objectives is the first crucial step in ROI methodology, which sets out five crucial levels of objectives at the concept and development stages to sell interactive technologies. The objective levels include reaction objectives, learning objectives, application objectives, impact objectives, and final ROI objective [40]. These productivity requirements are the preliminaries for the ROI perspective and are crucial in developing new techniques and business models. Different models may incorporate various costly stages. As an example, the cost of quality model (CoQ) consists of several layers of quality achievement. This model determines the costs of quality achievement within four areas: prevention costs, appraisal costs, internal failure costs, and external failure costs [41, 42].

\subsection{Emerging Advanced Techniques for Construction Projects.} As stated earlier, rethinking construction is necessary to reduce dissatisfaction with overall construction performance [12]. Force ([12], p. 4) identified four factors that are important for resolving the issue of client dissatisfaction, including "committed leadership, a focus on the customer, integrated processes and teams, and a quality-driven agenda and commitment to people." End-user dissatisfaction can originate from a lack of stakeholder satisfaction with the project. Lack of stakeholder satisfaction results in inefficiencies and vice versa, impeding project productivity. How to respond to the interests of stakeholders and manage their reactions within an organisation is crucial when managing stakeholders [43]. Further, stakeholder commitment regarding competent decisions made during the project improves the company performance [44]. Therefore, the need to improve productivity has paved the way for advanced and emerging techniques and technologies, each with their own characteristics. In recent years, advanced techniques, such as prefabrication, automation, and IT-based techniques, have drastically altered the construction industry, changing its focus from traditional practice to modern enterprise [45].

Agazzi ([46], p. 2) referred to a technique as "a display of practical abilities that allow one to perform easily and efficiently a given activity." Isman [47] defined a technique as having the practical knowledge to contribute to a procedure or a system and referred to technology as organising and practically applying knowledge to produce a concrete result. For example, modern construction is considered to be a technology [47], while the lean production and prefabrication contributing to potential modern construction are considered techniques. Therefore, the application of a new technique may be followed by creation of a new technology. The interdependent implementation of these advanced techniques as well as their concurrent applications under a well-defined systematic adoption forms potentially valuemaking leverage for the performance of construction projects [48].

Based on "productivity improvement strategies" [49], three steps can determine whether improvements are achieved by implementing new techniques and technologies: firstly, setting clear objectives; secondly, putting in place the pathways needed to achieve the objectives; and thirdly, sharing and comparing data to assess performance with other practitioners in the industry.

The ROI perspective has been useful in creating a range of new approaches and techniques, each with their own specific characteristics and particular potential to create improvements. The following sections discuss these functions.

2.3.1. Big Data. These newly advanced techniques generate high volumes of useful data that can contribute to improving productivity [50]. Therefore, they can be categorised as big data-inspired techniques, which, by definition, deal with the large amounts of information required for decision-making. The term "big data" refers to an industrial revolution brought about by the use of vast amounts of data-characterised by volume, variety, and velocity (the $3 \mathrm{Vs}$ ) - for business improvement, cost optimisation, and prediction of revenue [50]. The three basic functions of big data are recognition of customer priorities, prediction of market trends, and business process optimisation. This third function has been found to be applicable to the construction industry and to improve costeffectiveness. Cost reduction is the final outcome of the comprehensive information on cost-effectiveness provided by big data-directed techniques and tools. However, this requires a systematic workflow to extract the information applicable to the decision-making process [51]. Innovation of new services and products is a priority for reducing costs. An understanding of customer expectations, consumer concerns, and market prediction is an essential preliminary of process optimisation-another great outcome of big data, which contributes to the decision-making processes that influence the development of innovation. Process optimisation can be found applicable to the construction industry, which relies on cost-effective solutions. Bilal et al. [51] believed that the 3Vs of big data can influence productivity streamlining. However, 
this benefit requires a masterful, systematic workflow to extract constructive materials applicable into the decisionmaking process [51]. Shrestha [52] declared that a range of diverse data is generated within the phases of construction projects; these data are required to be processed, streamlined, and exchanged among stockholders during decision-making. This diversity of data can reflect the $3 \mathrm{Vs}$ of big data that configure the pathway towards improvements in efficiency during a building project's lifecycle [53]. Advanced techniques generate not only a high volume of data but also effective information that contributes to the improvement of productivity [50]. Therefore, it is claimable that the techniques are aligned with the objectives of big data concept and can be categorised as big data-inspired techniques.

The techniques outlined in this section are categorised as big data-based techniques, as their objectives are to provide the project's operating system with sophisticated information.

(1) Building Information Modelling (BIM). A revolutionary emergence, BIM, offers numerous precise and practical data to the construction industry, from an improved computeraided drawing (CAD) model, to the involvement of project stockholders in a multidisciplinary working environment [54]. BIM presents considerable potential for coordination, collaboration, and integration along with improvements in information flow and data processing that reach beyond the capacity of traditional construction methods [55].

Sabet and Chong [6] listed the leading practices of BIM as planning and scheduling, constructability assessment, 3-D model visualisation, clash detection, measurement and estimation, site management, safety management, and operation management-as last, but not the least.

Through these constructive practices, BIM has improved the construction industry from different perspectives, enabling stockholders to capture and process information within a project's various stages. Information transformation optimises the project procedure, contributing to perfect completion [56].

Ismail et al. [50] declared that BIM is not precisely equal to big data. However, Bilal et al. [51] claimed that the application of BIM, along with other advanced techniques and devices for procuring data, aligns with big data's mission to flourish within the industry of construction management.

(2) Augmented Reality (AR). AR is a technique by which captured images can be manipulated in the same way as they can in reality. In fact, the images can be linked to the real world, occupying the same spatial dimensions [57].

AR originated from virtual reality (VR), which partially but tangibly creates an environment wherein the operability of an object can be sensed and practised in real time to improve human understanding of it [58]. As the high-quality visualisation of details is very effective for reducing the complexity of information [51], it is claimed that the AR technique accords with big data's objective to generate information for better decision-making [59]. For example, AR is capable of being paired with BIM to enable designers to apply more maintainable and sustainable principles to their designs. This point improves facility management at the building operation stage [60].

(3) VR. VR is a technique via which users can experience the real working environment before project completion. This technique offers an "interactive 3D graphic, user interfaces, and visual simulation" ([61], p. 25). It has been found to be very useful for improving safety. VR training significantly improves the efficiency and productivity of "stone cladding work and cast-in-situ concrete work," saving the time that would be spent on conventional training [62]. Sacks et al. [62] stated that training via VR effectively attracts newcomers' attention and produces concision. Messner et al. [63] believed that VR helps trainees to understand certain technical details better. The trainees sensibly address "construction sequences, temporary facility locations, trade coordination, safety issue identification, and design improvements for constructability" ([63], p. 1).

(4) Blockchain. Crosby et al. [64] defined Blockchain as a technique through which not only the databases of records but also all transactions or digital activities are recorded and distributed among stockholders. Once entered, data never can be removed. Crosby et al. ([65], p. 280) expressed four characteristics of the blockchain:

(1) It is public, not owned by anybody, (2) it is decentral, not stored on one single computer but on many computers owned by different people across the world, (3) constantly synchronized to keep the transactions up to date, and (4) secured by cryptography to make it tamper proof and hacker proof.

Turk and Klinc [66] found blockchains to be capable of improving the construction industry by overcoming lost data and manipulating issues within the life-cycles of projects. "Smart construction relies on BIM for manipulating information flow, data flow, and management flow" ([67], p. 1), which the blockchain can address. The processes of unifying data, maintaining verifiable records, and keeping data permanently available make the blockchain relevant to both financial and nonfinancial schemes [64]. When it comes to the field of construction, the application of a blockchain to a smart contract is a bold move [67]. A blockchain can keep an accurate visible history of the actions users have taken across the network [68], thereby supporting the smart contract to be secured. All provisions and protocols can be permanently available in a chained structure, with no opportunity of change [66]. In such a situation, not only can all regulations be supervised, but the duties of users can also be tracked.

(5) Laser Scanning. Laser scanning is a technique by which actual, accurate data from an as-built situation are retrieved by scanning the work's progress or status. The data can then be used to evaluate quantities of work and to report progress [69] or for decision-making purposes [70]. El-Omari and Moselhi [71] believed that the accurate reporting of progress to management is a determinant action in the effective delivery of projects. The chance of a proper report is higher 
through 3D laser scanning, which is capable of highly accurate reporting through the provision of precise data. Su et al. [72] observed this technique to be very practical for improving the efficiency of urban underground works, where working spaces were restricted in terms of visibility and movement. Randall [73] described laser scanning as a complementary measure for BIM that could influence the various phases of projects, including programming, planning, design, construction, operation, and maintenance.

(6) Artificial Intelligence (AI) Techniques. In simple words, AIs are techniques whereby human perceptions can be transferred to machines, allowing them to perform the way humans supposedly would in complicated situations [74]. AI makes industries more efficient and effective, allowing intelligent automatic machines to "analyse the human's thinking system and reflect the same to reality" ([75], p. 1). This technique enables automatic machines to mimic human behaviours and operate intelligently [76]. Further, AI can refer to smart software, facilitating better technical information, management, and collaboration fields [77]. Therefore, the software directing robotic machinery can also be considered AI. Bose [78] discussed three main areas in which revolutionary AI has intervened. These areas are (1) quicker and more confident decision-making, (2) immediate accessibility and practical insights originating from big data, and (3) protection of susceptible data.

AIs have the potential to rapidly and imminently affect the construction industry by tackling industrial issues without physically involving humans in a complex working system [79]. Jose et al. [79] listed a range of potential fields within the construction industry that AIs could influence, including cost overrun, design optimisation, risk mitigation, planning, site productivity, safety, labour shortages, prefabrication, data generation, and building operation.

2.3.2. Off-Site Manufacture (OSM). OSM is a technique offering a combination of prefabricated components and onsite activities. The components are either erected to shape a constructed object or attached to in situ built components [80]. In fact, "the off-site components are produced in a controlled manufacture environment and then transported and positioned onto a construction site" ([81], p. 207). In 2017, the Sustainable Built Environment's National Research Centre (SBEnrc) declared that OSM was capable of providing the construction industry with optimal opportunities over the next decade [82]. These opportunities are significantly aligned with demands for affordable housing, set to double by 2021. Sabet and Chong [6] listed a range of OSM attributes arising from these opportunities: automation and series production, faster investment return, employment opportunities, sustainability, and safety.

2.3.3. Automation. Automation refers to a technique by which a procedure or a cycle of processes is carried out with minimal human involvement [83]. This technique makes industries more efficient and effective by applying software and hardware to complete tasks automatically. Through this highly beneficial technique, equipment, machinery, and processes are operated via controlling systems in complex situations. However, sometimes, a controlling system fails as a consequence of human-related error and any potential benefit is transformed into a loss or even a disaster [84]. Lee and See [84] believed that automation dramatically improves human performance and safety and provided that accurate data are entered into the system and its transformation is reliable. Automation not only has been observed to optimise construction site productivity but is also capable of promoting the mass production of prefabricated construction components in factories [85].

2.4. Productivity Indicators. Clear objectives are necessary to drive a dramatic improvement in productivity. These must be followed by constructive strategies, milestones, and identification of productivity indicators [12]. These indicators must reflect project inputs and contribute to project progress as process outputs. Productivity is "a relationship (usually a ratio or an index) between output (goods and/or services) produced by a given organizational system and quantities of input (resources) utilized by the system to produce that output" [86]. Force [12] believes that productivity indicators must be related to time, cost, quality, and predictability.

Sabet and Chong ([81], p. 4) explained that "input refers to materials (\$), personnel (P-H), and equipment (\$) put into the projects while output refers to production unit." Construction progress can be simulated for the production unit on construction sites. Construction activities are ranked as high-cost business activities. Thus, productivity achievement refers to the minimum input needed to achieve a reasonable output [87]. In the current paper, the terms productivity and performance and their borders within the construction field have been discussed as a preliminary to identification of productivity indicators. "Performance perspective from a broad sense can be followed by productivity perspective in a narrow sense" ([81], p. 4). This claim suggests that productivity can be deemed a consequence of performance. However, Dozzi and AbouRizk [88] stated that the term "productivity" equals performance.

Various indicators of productivity and performance have been reported. Socioeconomic conditions have been identified as the reason for this variety across different countries [89]. The indicators have been divided into quantitative and qualitative categories; quantitative indicators can be physically measured (numerical) using measurement scales. For example, these indicators might be scaled via a report on costs, material usage, completion of a proportion of activities, and number of crew members. Qualitative indicators refer to those that cannot be tangibly observed and scaled. These indicators do not show the exact data for a project trend but offer a description of a situation (e.g., a safety report) [90]. Sabet and Chong [81] offered a comprehensive conceptual framework that categorised KPrIs as company characteristics, labour, materials, management, documentation and regulations, machinery, contract conditions, IT involvement, and engineering and 
TABle 1: The supportive sources for this paper.

\begin{tabular}{|c|c|c|c|}
\hline No & The sources of the current paper & $\begin{array}{l}\text { The sources contributing to } \\
\text { productive fundamentals }\end{array}$ & $\begin{array}{l}\text { The sources confirming advanced technique definition } \\
\text { and their applications for performance }\end{array}$ \\
\hline 1 & He and Shi [1] & $\mathrm{X}$ & \\
\hline 2 & Stevens [2] & $\mathrm{X}$ & \\
\hline 3 & Sveikauskas et al. [3] & $\mathrm{X}$ & \\
\hline 4 & Green [4] & $\mathrm{X}$ & \\
\hline 5 & Bronte-Stewart [5] & $\mathrm{X}$ & $\mathrm{X}$ \\
\hline 6 & Sabet, Chong [6] & $\mathrm{X}$ & $\mathrm{X}$ \\
\hline 7 & McGeorge and Zou [7] & $\mathrm{X}$ & \\
\hline 8 & Changali et al. [8] & $\mathrm{X}$ & \\
\hline 9 & Richardson [9] & $\mathrm{X}$ & \\
\hline 10 & Bresnen and Marshall [10] & $\mathrm{X}$ & \\
\hline 11 & Ganesan [11] & & \\
\hline 12 & Force [12] & $\mathrm{X}$ & \\
\hline 13 & Winch [13] & $\mathrm{X}$ & \\
\hline 14 & Enshassi and Burgess [14] & & $\mathrm{X}$ \\
\hline 15 & Fellows and Liu [15] & & $\mathrm{X}$ \\
\hline 16 & Park $[16]$ & & $\mathrm{X}$ \\
\hline 17 & Bassioni et al. [17] & & $\mathrm{X}$ \\
\hline 18 & Abd El-Razek et al. [18] & & $\mathrm{X}$ \\
\hline 19 & Azhar et al. [19] & $\mathrm{X}$ & \\
\hline 20 & Durdyev and Ismail [20] & & $\mathrm{X}$ \\
\hline 21 & Naoum [21] & & $\mathrm{X}$ \\
\hline 22 & Emmitt and Gorse [22] & & $\mathrm{X}$ \\
\hline 23 & Meng [23] & & $\mathrm{X}$ \\
\hline 24 & Lavender [24] & $\mathrm{X}$ & \\
\hline 25 & Kazaz and Ulubeyli [25] & & $\mathrm{X}$ \\
\hline 26 & Jarkas and Radosavljevic [26] & $\mathrm{X}$ & \\
\hline 27 & Jaffar et al. [27] & & $\mathrm{X}$ \\
\hline 28 & Shohet and Laufer [28] & $\mathrm{X}$ & \\
\hline 29 & Islam and Khadem [29] & & $\mathrm{X}$ \\
\hline 30 & Jarkas and Bitar [30] & & $\mathrm{X}$ \\
\hline 31 & Aziz and Hafez [31] & & $\mathrm{X}$ \\
\hline 32 & Mills [32] & $\mathrm{X}$ & \\
\hline 33 & Wang et al. [33] & $\mathrm{X}$ & \\
\hline 34 & Singh [34] & $\mathrm{X}$ & \\
\hline 35 & Alwi $[35]$ & & $\mathrm{X}$ \\
\hline 36 & Ghoddousi and Hosseini [36] & $\mathrm{X}$ & \\
\hline 37 & Thomas et al. [37] & & $\mathrm{X}$ \\
\hline 38 & Abrey and Smallwood [38] & & $\mathrm{X}$ \\
\hline 39 & Hanna and Heale [39] & $\mathrm{X}$ & \\
\hline 40 & Wagner and Derryberry [40] & $\mathrm{X}$ & \\
\hline 41 & Samson and Terziovski [41] & $\mathrm{X}$ & \\
\hline 42 & Jafari and Love [42] & $\mathrm{X}$ & \\
\hline 43 & Jepsen and Eskerod [43] & $\mathrm{X}$ & \\
\hline 44 & Song et al. [44] & $\mathrm{X}$ & \\
\hline 45 & Nam et al. [45] & & $\mathrm{X}$ \\
\hline 46 & Agazzi [46] & & $\mathrm{X}$ \\
\hline 47 & Isman $[47]$ & & $\mathrm{X}$ \\
\hline 48 & Nguyen and Akhavian [48] & & $\mathrm{X}$ \\
\hline 49 & Gunasekaran and Cecille [49] & $\mathrm{X}$ & \\
\hline 50 & Ismail et al. [50] & & $\mathrm{X}$ \\
\hline 51 & Bilal et al. [51] & & $\mathrm{X}$ \\
\hline 52 & Shrestha [52] & & $\mathrm{X}$ \\
\hline 53 & Motawa [53] & & $\mathrm{X}$ \\
\hline 54 & Eadie et al. [54] & & $\mathrm{X}$ \\
\hline 55 & Li et al. [55] & & $\mathrm{X}$ \\
\hline 56 & Azhar [56] & & $\mathrm{X}$ \\
\hline 57 & Azuma et al. [57] & & $\mathrm{X}$ \\
\hline 58 & Jiao et al. [58] & & $\mathrm{X}$ \\
\hline 59 & Olshannikova et al. [59] & & $\mathrm{X}$ \\
\hline
\end{tabular}


Table 1: Continued.

\begin{tabular}{|c|c|c|c|}
\hline No & The sources of the current paper & $\begin{array}{l}\text { The sources contributing to } \\
\text { productive fundamentals }\end{array}$ & $\begin{array}{l}\text { The sources confirming advanced technique definition } \\
\text { and their applications for performance }\end{array}$ \\
\hline 60 & Khalek et al. [60] & & $\mathrm{X}$ \\
\hline 61 & Zyda [61] & & $\mathrm{X}$ \\
\hline 62 & Sacks et al. [62] & & $\mathrm{X}$ \\
\hline 63 & Messner et al. [63] & & $\mathrm{X}$ \\
\hline 64 & Crosby et al. [64] & & $\mathrm{X}$ \\
\hline 65 & Belle [65] & & $\mathrm{X}$ \\
\hline 66 & Turk and Klinc [66] & & $\mathrm{X}$ \\
\hline 67 & Zheng et al. [67] & & $\mathrm{X}$ \\
\hline 68 & Pilkington [68] & & $\mathrm{X}$ \\
\hline 69 & El-Omari and Moselhi [69] & & $\mathrm{X}$ \\
\hline 70 & Goedert and Meadati [70] & $\mathrm{X}$ & \\
\hline 71 & El-Omari and Moselhi [71] & $\mathrm{X}$ & $\mathrm{X}$ \\
\hline 72 & Su et al. [72] & & $\mathrm{X}$ \\
\hline 73 & Randall [73] & & $\mathrm{X}$ \\
\hline 74 & Chen et al. [74] & & $\mathrm{X}$ \\
\hline 75 & Dede et al. [75] & & $\mathrm{X}$ \\
\hline 76 & Nau [76] & & $\mathrm{X}$ \\
\hline 77 & Anumba et al. [77] & & $\mathrm{X}$ \\
\hline 78 & Bose $[78]$ & $\mathrm{X}$ & \\
\hline 79 & Jose et al. [79] & & $\mathrm{X}$ \\
\hline 80 & Blismas and Wakefield [80] & & $\mathrm{X}$ \\
\hline 81 & Sabet and Chong [81] & $\mathrm{X}$ & $\mathrm{X}$ \\
\hline 82 & SBEnrc [82] & & $\mathrm{X}$ \\
\hline 83 & Groover [83] & & $\mathrm{X}$ \\
\hline 84 & Lee and See $[84]$ & & $\mathrm{X}$ \\
\hline 85 & Neelamkavil [85] & & $\mathrm{X}$ \\
\hline 86 & Hannula [86] & $\mathrm{X}$ & \\
\hline 87 & Huang et al. [87] & $\mathrm{X}$ & \\
\hline 88 & Dozzi and AbouRizk [88] & $\mathrm{X}$ & \\
\hline 89 & Hasan et al. [89] & $\mathrm{X}$ & \\
\hline 90 & Cox et al. [90] & $\mathrm{X}$ & \\
\hline 91 & Golnaraghi et al. [91] & $\mathrm{X}$ & \\
\hline 92 & Elnaas et al. [92] & & $\mathrm{X}$ \\
\hline 93 & Lessing et al. [93] & & $\mathrm{X}$ \\
\hline 94 & Pasquire and Connolly [94] & & $\mathrm{X}$ \\
\hline 95 & Durdyev and Ismail [95] & & $\mathrm{X}$ \\
\hline 96 & Ding et al. [96] & & $\mathrm{X}$ \\
\hline 97 & Kang et al. [97] & & $\mathrm{X}$ \\
\hline 98 & Li et al. [98] & & $\mathrm{X}$ \\
\hline 99 & Lee et al. [99] & & $\mathrm{X}$ \\
\hline 100 & Chen and Luo [100] & & $\mathrm{X}$ \\
\hline 101 & Khoshnava et al. [101] & & $\mathrm{X}$ \\
\hline 102 & Sulankivi et al. [102] & & $\mathrm{X}$ \\
\hline 103 & Wang and Love [103] & & $\mathrm{X}$ \\
\hline 104 & Smith [104] & & $\mathrm{X}$ \\
\hline 105 & Li et al. [105] & & $\mathrm{X}$ \\
\hline 106 & Wong et al. [106] & & $\mathrm{X}$ \\
\hline 107 & Behzadi [107] & & $\mathrm{X}$ \\
\hline 108 & Shen et al. [108] & $\mathrm{X}$ & \\
\hline 109 & Pan et al. [109] & & $\mathrm{X}$ \\
\hline 110 & Zhao and Lucas [110] & & $\mathrm{X}$ \\
\hline 111 & Fang et al. [111] & & $\mathrm{X}$ \\
\hline 112 & Oudshoorn [112] & & $\mathrm{X}$ \\
\hline 113 & Gleason [113] & & $\mathrm{X}$ \\
\hline 114 & Huber et al. [114] & & $\mathrm{X}$ \\
\hline 115 & Tapscott andA. Tapscott [115] & & $\mathrm{X}$ \\
\hline 116 & Kassem et al.[116] & & $\mathrm{X}$ \\
\hline 117 & Lu et al. $[117]$ & & $\mathrm{X}$ \\
\hline 118 & Brandenburger et al. [118] & & $\mathrm{X}$ \\
\hline 119 & Wamba et al. [119] & & $\mathrm{X}$ \\
\hline
\end{tabular}


TABle 1: Continued.

\begin{tabular}{lccc}
\hline No & The sources of the current paper & $\begin{array}{c}\text { The sources contributing to } \\
\text { productive fundamentals }\end{array}$ & $\begin{array}{c}\text { The sources confirming advanced technique definition } \\
\text { and their applications for performance }\end{array}$ \\
\hline 120 & Sørensen et al. [120] & & $\mathrm{X}$ \\
121 & Balaguer and Abderrahim [121] & $\mathrm{X}$ & $\mathrm{X}$ \\
122 & Hegazy et al. [122] & $\mathrm{X}$ & $\mathrm{X}$ \\
123 & Elfaki et al. [123] & $\mathrm{X}$ & $\mathrm{X}$ \\
124 & Ppeleska [124] & & $\mathrm{X}$ \\
125 & Zou et al. [125] & $\mathrm{X}$ & \\
126 & Meadati [126] & Ji et al [127] & \\
127 & Gurmu and Ongkowijoyo [128] & & \\
128 & &
\end{tabular}

Step 1: clarification of the scope
Aim: to develop an integrated framework for applying a range of productivity
fundamentals to increase the capacity of advanced techniques to deliver the expected
improvements in productivity

FIGURE 1: The procedures used in the scoping review.

external circumstances. Among other indicators, improved productivity is guaranteed by an appropriate management style $[14,15]$ and the implementation of well-structured techniques [13].

\section{Methodology}

For this scoping review, a micro-to-macro method was used to assemble the relevant literature. Each dimension of this twodimensional view interacts with the other for a more efficient analysis [40] of the requirements for the development and application of advanced techniques. Here, the microdimension examines the range of productivity fundamentals as the supplementary foundation on which advanced techniques should be applied, while the macrodimension focuses on the stages at which these fundamentals need to be applied. Further, a holistic understanding of the selected advanced techniques is provided through the literature review. This review method links the evidence retrieved from the literature to justify the designated objectives. This method is particularly relevant in the case of new topics on which the literature is scarce [81]. Table 1 shows the sources reviewed to evident this paper's claim. Also, Figure 1 shows how the method was developed in this study. 
TABLE 2: Advanced techniques and their effects on construction projects.

\begin{tabular}{|c|c|c|c|}
\hline Advanced techniques & Performance aspects & Ways in which construction projects can be influenced & Sources \\
\hline \multirow{5}{*}{ Off-site manufacture } & Time & $\begin{array}{l}\text { Since better quality control can be achieved in a more controlled working environment } \\
\text { (OSM-based project), the chance of any re-work disturbing planning and scheduling in a } \\
\text { project is minimised. }\end{array}$ & {$[82,92,93]$} \\
\hline & Cost & $\begin{array}{c}\text { 24-hour availability of materials in factory stock reduces the time needed for ordering and } \\
\text { transferring materials and thus the total project time. Shorter project completion times } \\
\text { mean lower overhead expenses. Better quality control can prevent potentially costly re- } \\
\text { work. Better waste management is possible in a factory environment; all these factors } \\
\text { improve project cost performance. }\end{array}$ & {$[82,94]$} \\
\hline & Quality & $\begin{array}{l}\text { Better monitoring of construction processes to produce the construction elements in a } \\
\text { controlled environment leads to improved achievement of specifications, which contributes } \\
\text { to quality performance }\end{array}$ & {$[82,93]$} \\
\hline & Safety & $\begin{array}{l}\text { Safety considerations are easier to observe in a factory environment where prefabricated } \\
\text { construction components are produced. Occupational health and safety principles can } \\
\text { efficiently and effectively imposed and monitored in a controlled work environment }\end{array}$ & {$[80,82]$} \\
\hline & Stakeholder satisfaction & $\begin{array}{l}\text { Stakeholder satisfaction is achievable by systematic adoption of advanced techniques. } \\
\text { Respondent satisfaction has been reported for "reduced construction periods, on-site } \\
\text { construction and labour costs, and improved quality, there still is room to overweight safety } \\
\text { and waste subjects of OSM-based projects and compare them with that of non-OSM-based } \\
\text { projects. It is mentionable that the level of adoption and how the adoption should be } \\
\text { organised can play a determinant role in stakeholder satisfaction." }\end{array}$ & $([95]$, p. 1) \\
\hline \multirow{7}{*}{$\begin{array}{l}\text { Building information } \\
\text { modelling }\end{array}$} & Time & $\begin{array}{l}\text { The coincidence of 3-D model of designs in a virtual environment can reveal any potential } \\
\text { interference between building activities, limiting the chance of any time-consuming } \\
\text { modifications of initial planning and scheduling while the project is in progress. } \\
\text { Through a virtual model supported by an information-sharing platform in BIM, the parties } \\
\text { involved in a project can be linked together to evaluate any potentially conflicting } \\
\text { situations, and a rapid decision can be made in the case of any confusion that may affect } \\
\text { project progress. }\end{array}$ & {$[96,97]$} \\
\hline & Cost & $\begin{array}{l}\text { Limiting the chance of re-work and safety issues directly influence cost performance. In } \\
\text { addition, a BIM model equipped with planning and scheduling tools enables the relevant } \\
\text { experts to optimise resource management, which helps optimise cost performance }\end{array}$ & [98] \\
\hline & Quality & $\begin{array}{l}\text { A high-quality virtual model rapidly clarifies information related to materials specifications } \\
\text { and the delivery details of certain activities, such as the dispatch and assembly of } \\
\text { prefabricated components at the construction site. This limits the chance of poor } \\
\text { performance, contributing to improved quality assurance. }\end{array}$ & [99] \\
\hline & Safety & $\begin{array}{l}\text { Dynamic safety analysis can be practised via the virtual site model offered by BIM. } \\
\text { Modelling certain operations, such as cranes and plants, improves safety management. A } \\
\text { virtual site layout contributes to the effective management of safety considerations } \\
\text { Greater practical clarification is possible by using a virtual environment to improve } \\
\text { workers' knowledge, thereby avoiding potentially hazardous situations. }\end{array}$ & {$[100-102]$} \\
\hline & Quality & $\begin{array}{c}\text { By reviewing the processes involved in certain activities with the workforce, the chance of } \\
\text { errors or defect in the end product can be limited. }\end{array}$ & \\
\hline & Stakeholder satisfaction & $\begin{array}{l}\text { Easy sharing of information via BIM can contribute to stakeholder satisfaction as they can } \\
\text { better understand the other parties' work scope and processes and coordinate their activities } \\
\text { accordingly, limiting the chance of potential ambiguities or interference. This theme } \\
\text { optimises multidisciplinary coordination and provides a better collaborative environment. } \\
\text { The BIM model has excellent capability for determining measures and estimations of site } \\
\text { activities. Highly accurate estimation could be offered accordingly, thus reducing excess } \\
\text { costs. }\end{array}$ & {$[55,100,103,104]$} \\
\hline & Cost & $\begin{array}{l}\text { The optimal operations of cranes and trucks can be modelled in a BIM, and operators } \\
\text { advised accordingly to achieve efficient performance. This also optimises the energy } \\
\text { resources necessary to operate the site machinery efficiently. }\end{array}$ & \\
\hline \multirow{4}{*}{ Augmented reality } & Time & $\begin{array}{l}\text { Time performance is crucial for the implementation of a site schedule. Visually monitoring } \\
\text { project progress so that as-built elements can be compared to the as-planned form of the } \\
\text { elements can contribute to optimal schedule monitoring, improving time performance. } \\
\text { AR provides practitioners a model of the actual site in a virtual environment to compare } \\
\text { with the as-built components, which allows quicker inspections and improves decision- } \\
\text { making processes. }\end{array}$ & [105] \\
\hline & Cost & $\begin{array}{l}\text { AR limits the chance of misinterpreting drawings and exchanging imprecise data. These } \\
\text { factors are the main source of time and cost overruns. }\end{array}$ & [106] \\
\hline & Quality & $\begin{array}{l}\text { AR supports automation, which allows optimum operation by the user and minimises } \\
\text { defects of operation. }\end{array}$ & \\
\hline & Stakeholder satisfaction & $\begin{array}{l}\text { An AR system allows practitioners to make virtual site visits. This can contribute to safety } \\
\text { performance by highlighting any unseen potential threats without an actual inspection. } \\
\text { Effective communication and information exchange between the parties involved in the } \\
\text { project contribute to stakeholder satisfaction. The additional visualisation capability of AR } \\
\text { and the ease of access to information and sharing information via lightweight devices } \\
\text { improve the stakeholder satisfaction. }\end{array}$ & [107] \\
\hline
\end{tabular}


TABLE 2: Continued.

\begin{tabular}{|c|c|c|c|}
\hline Advanced techniques & Performance aspects & Ways in which construction projects can be influenced & Sources \\
\hline \multirow{4}{*}{ Virtual reality } & Time and cost & $\begin{array}{l}\text { Measures such as training the workforce in a virtual environment and simulating certain } \\
\text { activities related to quality improvement lead to effective defect management via VR. This } \\
\text { minimises the chance of overlooking any requirements or specifications consuming, which } \\
\text { can be costly and time-consuming to rectify. }\end{array}$ & Reference [108] \\
\hline & Quality & $\begin{array}{l}\text { Machine and equipment operators can be highly trained before they start work on the site. } \\
\text { The wider workforce can be trained for certain activities through e-learning in VR. For } \\
\text { example, steel erection and the placement of installation elements can be modelled in VR. } \\
\text { Therefore, a VR platform can improve the quality of work. }\end{array}$ & {$[109,110]$} \\
\hline & Safety & $\begin{array}{c}\text { Training of the workforce is a major concern before beginning construction. VR provides } \\
\text { an effective platform for training in a virtual environment }\end{array}$ & [111] \\
\hline & Stakeholder satisfaction & $\begin{array}{l}\text { Detailed visualisation via VR provides all parties with a better understanding of the } \\
\text { expectations of others and how to better cooperate throughout the project. This enables a } \\
\text { dynamic process for the protection of key values, openness between parties, and } \\
\text { competitive progress. }\end{array}$ & [112] \\
\hline \multirow{4}{*}{ Laser scanning } & Time & $\begin{array}{l}\text { In the absence of information on as-built elements, laser scanning contributes to decision- } \\
\text { making by offering the information required for the existing components or building to } \\
\text { plan any changes or renovations. }\end{array}$ & {$[113,114]$} \\
\hline & & $\begin{array}{l}\text { Laser scanning offers accurate data for the production of documentation via capturing and } \\
\text { recording construction progress (as-built preparation). The risk of the production of faulty } \\
\text { documentation that may offer erroneous information is limited. The identification of faults } \\
\text { would take time. }\end{array}$ & [70] \\
\hline & Quality & $\begin{array}{l}\text { The data offered by laser scanning can be used to monitor and evaluate construction } \\
\text { progress if it is in compliance with the specifications as per the drawings. This contributes to } \\
\text { quality assurance }\end{array}$ & {$[113,114]$} \\
\hline & Cost & $\begin{array}{c}\text { Laser scanning is useful for measuring the materials required and accurate calculation of } \\
\text { materials orders, limiting the chances of waste. }\end{array}$ & [69] \\
\hline \multirow[t]{2}{*}{ Blockchain } & Stockholder satisfaction & $\begin{array}{l}\text { Modern management encourages the architecture, engineering, and construction } \\
\text { industries to accelerate digitalisation in architectural and engineering procedures, in tender } \\
\text { and contract ventures and even during prefabrication for use in construction sites. The } \\
\text { blockchain eliminates any chance of data loss and manipulation that may necessitate } \\
\text { additional costs through data restoration. Thus, the potential for disputes among the parties } \\
\text { involved in a project would be limited. }\end{array}$ & {$[65,115]$} \\
\hline & Time and cost & $\begin{array}{l}\text { Quick and reliable access to data and information is possible by referring to the } \\
\text { decentralised blockchain database. This not only saves transactional data costs, but also } \\
\text { develops a trusting environment for collaboration. }\end{array}$ & [116] \\
\hline \multirow[t]{2}{*}{ Big data } & $\begin{array}{l}\text { Time, cost and } \\
\text { stockholder satisfaction }\end{array}$ & $\begin{array}{l}\text { Big data-based techniques tangibly affect waste management optimisation that contributes } \\
\text { to project performance. These techniques reinforce the reliability of indexes developed for } \\
\text { performance measurement. The waste management rate as a reliable index is one example } \\
\text { resulting from the application of big data that has created a benchmark for project } \\
\text { performance in Hong Kong. }\end{array}$ & {$[51,117]$} \\
\hline & Quality & $\begin{array}{l}\text { Simple and fast access to high resolution data to monitor quality is an output of big data- } \\
\text { mining techniques. Quality can be effectively tracked by integrating reliable data from } \\
\text { various sources. }\end{array}$ & [118-120] \\
\hline \multirow{3}{*}{ Automation and $\mathrm{AI}$} & Time and cost & $\begin{array}{l}\text { A high volume of complicated construction-related jobs can be successfully accomplished } \\
\text { within a very much shorter time period using automatic robots as hardware and tools. } \\
\text { Further, smart software can be used to optimise certain processes (e.g., resource allocation } \\
\text { and levelling) and to produce reliable data. The chance of any errors resulting in delays and } \\
\text { costly reworking is limited by automation. However, additional costs may be incurred as a } \\
\text { result of its application. }\end{array}$ & {$[121,122]$} \\
\hline & $\begin{array}{l}\text { Time and stockholder } \\
\text { satisfaction }\end{array}$ & $\begin{array}{l}\text { Some AI agents are capable not only of providing technical information, such as cost } \\
\text { estimation, but also of leveraging collaborative environments by solving time and distance } \\
\text { issues. In fact, smart software tools provide stockholders with effective communication } \\
\text { tools. }\end{array}$ & {$[77,123]$} \\
\hline & Safety & $\begin{array}{l}\text { Complicated procedures and substantial physical activities create a significant risk of } \\
\text { human error that results in injury. Automation considerably eliminates situations in which } \\
\text { crew members may become injured. }\end{array}$ & {$[124]$} \\
\hline
\end{tabular}

The first step was to identify the root causes of poor productivity in the construction industry. Recent advanced techniques that affect project operating systems were examined to establish the pathways through which the different aspects of performance can be improved. To this end, the areas of resources, management, engineering, and innovation were searched. The next stage involved finding relevant sources by collecting and filtering documents to retrieve credible evidence to substantiate the arguments made in this paper. Documents were identified by searching
Google Scholar and scientific databases using keywords, including "construction project stages," "construction productivity," "construction performance," "advanced techniques in construction," and "productivity considerations." Next, the abstracts of the articles identified scanned to assess the relevance of the paper, and those of interest were evaluated to develop a clear understanding of the issues and requirements for construction productivity and productivity fundamentals, the stages at which these fundamentals should be applied and the capabilities of the relevant 
TABLe 3: Productivity fundamentals.

\begin{tabular}{lc}
\hline Productivity fundamentals & Relevant project stages \\
\hline Focus the value of the project only on what is required & Concept and design \\
Maintain a lifecycle concept of both construction and operation costs & Evaluation of alternative scenarios during project planning to overcome unexpected issues \\
Consider site conditions to optimise design & \\
Involve modular elements and standardisation during the design & Contracting and procurement \\
Stakeholder involvement in the design phase & \\
Optimisation of engineering procedures & \\
Share risk between all stakeholders and reflect this in the contract & Execution \\
Align the profits of the contractor and the owner as an incentive for early completion & \\
Clarify the need for costly items to the owner & \\
\hline Updating and adjustable planning for microplans in case of overlooked requirements and troubleshooting & \\
Employ prefabricated components & Consider energy saving strategies \\
Apply waste minimising strategies
\end{tabular}

advanced techniques. The research questions were then developed, asking what the state of construction productivity and performance is, and how to reinforce the implementation of advanced techniques to fulfil the project objectives and meet the expected return.

\section{Findings and Data Analysis}

The highly dynamic nature of construction projects can be challenging to their progress [91]. Difficult situations can be exacerbated if advanced techniques are not fundamentally supported in an organised and proper manner to fulfil their objectives. He and Shi [1] believed that an "effective construction organisation plan" is central to a construction optimisation model that results in project performance. Sabet and Chong [6] have claimed that the debate around productivity is aligned with that of performance in the construction industry. They state that the expected outcome of performance in the boarder sense is achievable through the improvement of productivity indicators in the narrow sense. This means that performance achievement is not straightforward, unless the required agents involved in productivity play a vital role in influencing a project's work flow.

Table 2 gives a summary of credible sources indicating how the recent highlighted advanced techniques have successfully influenced the aspects of construction performance so far.

\section{Integrated Framework}

Based on the explanations given in Table 2, each technique is able to influence certain KPrIs only. The uncovered KPrIs appear as devaluing agents for the techniques to meet the expected productivity improvement. In other words, even though the productive capabilities of the techniques that can constructively impact the project productivity, the potential gap contradictory appears that entirely disrupts the performance achievement.

A range of productivity fundamentals are necessary over the lifecycle of a project to improve productivity via the implementation of these advanced techniques. These fundamentals are complementary and can reinforce the capacity of advanced techniques to increase productivity. Integration management is essential for the implementation of the essential elements of productivity and advanced technique. A successful establishment of management relies on close communication between project participants throughout a project's lifecycle [1]. “The life cycle of a construction project is normally divided into a few stages, including conceptual (feasibility), design, construction, and operation stages" ([125], p. 603). Meadati [126] includes "planning, design, construction, operation and maintenance, and decommissioning" in the construction project lifecycle. A range of productivity fundamentals have been identified in the literature as complementary to the capabilities of the new advanced techniques. These fundamentals can be potentially applied during the concept and design, contracting and procurement, and execution stages of a construction project (Table 3).

The integrated framework shown in Figure 2 attempts to conceptualise the productivity fundamentals that need to be applied to support the implementation of advanced techniques. A range of productivity fundamentals (listed in Table 3) can be applied throughout in at least three stages of a project (concept and design, contracting and procurement, and execution) once one of the advanced techniques is implemented. To depict it, Figure 2 reflects that productivity indicators can be improved by the potential capabilities of new advanced techniques that can be reinforced with a range of productivity fundamentals. The productivity fundamentals and the advanced techniques directly and indirectly impact the categories of KPrIs, as highlighted in the process stage in Figure 2. The pathways through which the aspects of performance are improved have been discussed in Table 2. Overall, the project performance depends on both practising the fundamentals and the capabilities of the advanced techniques at the preconstruction and construction stages.

This paper theorises an enriched foundation with a range of productivity fundamentals that the new advanced techniques can be drawn on. The paper presents a conceptualisation of a productivity-performance network with 


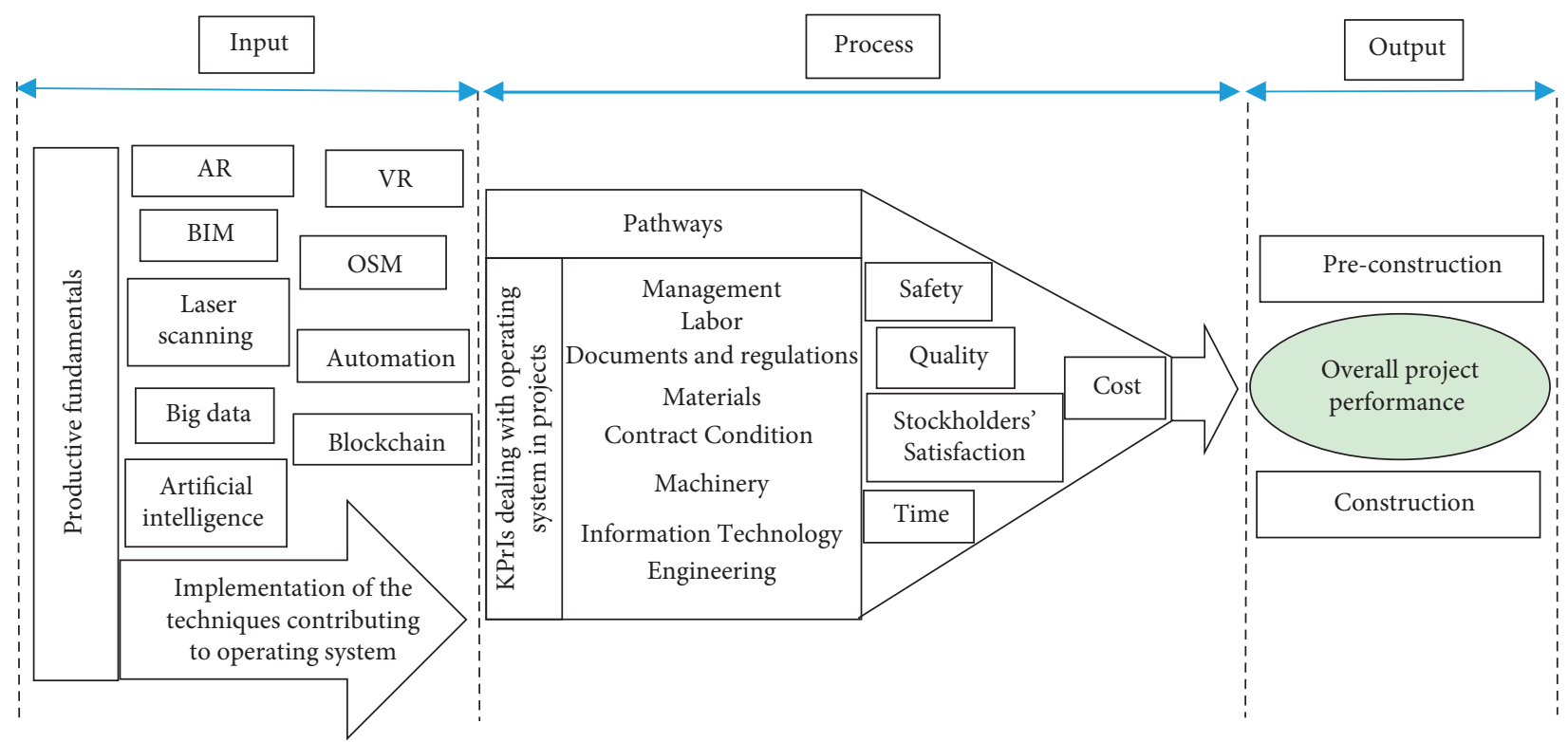

Figure 2: Productivity fundamentals for advanced techniques.

TABle 4: Potential roots of poor productivity.

Potential roots of poor productivity Sources that contribute to confirm these roots

Poor organisation $[18,19]$

Inappropriate relationship management and communication among stockholders

[20-23]

Ineffective management style

$[24,25]$

Lack of technical specifications and contract clarification

$[26,27]$

Lack of skilled crew members and inefficient connection with the crew

[28-30]

Untracked planning/scheduling (poor project control)

Lack of risk management allocation

Competencies mismanagement

$[29,34]$

Lack of upgraded equipment, methods, and materials

$[35-37]$

Lack of satisfactory working conditions

$[38,39]$

the techniques necessary for achieving reasonable overall project performance and also addresses the stages at which these fundamentals can be employed to realise potential improvements.

\section{Discussion and Conclusion}

The call for improved construction productivity implies that efforts toward improvements in the construction industry have not fulfilled expectations. Exploring new ways of achieving improvements requires the identification of weaknesses and strengths, and offering practical strategies that align with the pace of the evolution of technology. The implementation of advanced techniques in the construction industry is essential for project success [127] in such a competitive business world. Aziz and Hafez [31] stated that, over the past 40 years, although several advanced techniques that contribute to modernization of the construction, the expected efficiency level followed by the required productivity has not been satisfied. Advanced techniques have emerged to satisfy stockholder and end-user demands for productivity. However, these techniques are not capable of addressing all productivity indicators. Further, the lack of conditions in which these techniques may flourish diminishes their capacity. These conditions are referred to as productivity fundamentals in this paper. Awareness of the productivity fundamentals required to reinforce the implementation of advanced techniques is necessary for practitioners. Developing new, consistent, and advanced techniques with higher capacities to meet productivity expectations is the target of construction management. Our micro-to-macro methodology was saturated by scoping review. The scoping review of 128 credible sources was undertaken to develop a holistic understanding of the productivity requirements in the construction industry and clarify how the new advanced techniques impact the broader scale of productivity and performance. Table 2 summarises how these advanced techniques contribute to project operating systems. It highlights that each technique has its own characteristics that need to be paired with a range of productivity fundamentals. Higher productivity is dependent on better project operating systems. What fundamentals and how to apply them to improve productivity and achieve better performance may be a headline in the construction 
industry. Hundred and four credible sources, including journal articles and several industry reports, were analysed to provide the evidence to substantiate the arguments presented in this paper. This research identified the KPrI categories and the root causes of poor productivity (Table 4). A range of productivity fundamentals (Table 3) was developed, followed by a conceptual framework (Figure 2) to conceptualise how to equip a new advanced technique. It was shown that the KPrI categories could be merged into the aspects of performance (See Section 2 in Figure 2). Section 1 shows that the advanced techniques need to be supported by productivity fundamentals. Applying these techniques, along with the productivity fundamentals is key to improving overall productivity. The potential for successful implementation refers to the performance pathways outlined in this paper. Thus, by offering a more analytical perspective, this paper has addressed a range of productivity fundamentals that operate throughout all three stages of a project: concept and design, contracting and procurement, and execution. The construction industry would dramatically benefit from new advanced techniques that are based on the productivity fundamental categories. Figure 2 conceptualised the performance achievement at the preconstruction and construction stages through the range of fundamentals that can be integrated to practice these techniques. Further investigation to highlight the degree of impact of the productivity fundamentals in an empirical study is recommended.

\section{Limitation of the Research}

The role of qualified craft/skilled workforce availability that lies in labour productivity $[3,9]$ as well as their management style [128] are inseparable from the construction productivity theme. The role of newly emerged techniques and the adopted appropriate technique are the other drivers that affect the construction productivity. The scope of this paper focuses on the role of newly emerged techniques in the productivity only, which excludes the aspect of workforce availability.

\section{Conflicts of Interest}

The authors declare that they have no conflicts of interest.

\section{Acknowledgments}

The authors would like to acknowledge the contribution of an Australian Government Research Training Programme Scholarship and Australian Research Council (ARC).

\section{References}

[1] W. He and Y. Shi, "Multi objective construction optimization model based on quantum genetic algorithm," Advances in Civil Engineering, vol. 2019, Article ID 5153082, 8 pages, 2019.

[2] M. Stevens, Construction Productivity in Decline, The Magazine for Professional Engineers, Alexandria, VA, USA, 2014.
[3] L. Sveikauskas, S. Rowe, J. Mildenberger, J. Price, and A. Young, "Productivity growth in construction," Journal of Construction Engineering and Management, vol. 142, no. 10, Article ID 04016045, 2016.

[4] B. Green, Productivity in Construction: Creating a Framework for the Industry to Thrive, The Chartered Institute of Building (CIOB), Bracknell, UK, 2016, https://policy.ciob.org/wpcontent/uploads/2016/05/CIOB-Productivity-report-2016-v4_ single.pdf.

[5] M. Bronte-Stewart, "Beyond the iron triangle: evaluating aspects of success and failure using a project status model," Computing \& Information Systems, vol. 19, no. 2, pp. 19-36, 2015.

[6] P. Sabet and H. Y. Chong, "A conceptual hybrid OSM-BIM framework to improve construction project performance," in Proceedings of the Educating Building Professionals for the Future in the Globalised World, pp. 204-213, Singapore, September 2018.

[7] D. McGeorge and P. X. W. Zou, Construction Management: New Directions, John Wiley \& Sons, New York, NY, USA, 2012.

[8] S. Changali, A. Mohammad, and M. Nieuwland, The Construction Productivity Imperative, McKinsey \& Co., New York, NY, USA, 2015, https://www.mckinsey.com/ industries/capital-projects-and-infrastructure/our-insights/ the-construction-productivity-imperative.

[9] D. Richardson, Productivity in the construction industry, Vol. 33, The Australia Institute, Canberra, Australia, 2014.

[10] M. Bresnen and N. Marshall, "Partnering in construction: a critical review of issues, problems and dilemmas," Construction Management and Economics, vol. 18, no. 2, pp. 229-237, 2000.

[11] S. Ganesan, "Construction Productivity," Habitat International, vol. 8, no. 3-4, pp. 29-42, 1984.

[12] T. Force, Rethinking Construction, Department of the Environment, London, UK, 1998, http://constructingexcellence.org. uk/wpcontent/uploads/2014/10/rethinking\%20construction\% 20report.pdf.

[13] G. Winch, "Zephyrs of creative destruction: understanding the management of innovation in construction," Building Research \& Information, vol. 26, no. 5, pp. 268-279, 1998.

[14] A. Enshassi and R. Burgess, "Managerial effectiveness and the style of management in the Middle East: an empirical analysis," Construction Management and Economics, vol. 9, no. 1, pp. 79-92, 1991.

[15] R. Fellows and A. M. M. Liu, "Managing organizational interfaces in engineering construction projects: addressing fragmentation and boundary issues across multiple interfaces," Construction Management and Economics, vol. 30, no. 8, pp. 653-671, 2012.

[16] H.-S. Park, "Conceptual framework of construction productivity estimation," KSCE Journal of Civil Engineering, vol. 10, no. 5, pp. 311-317, 2006.

[17] H. A. Bassioni, A. D. F. Price, and T. M. Hassan, "Performance measurement in construction," Journal of Management in Engineering, vol. 20, no. 2, pp. 42-50, 2004.

[18] M. E. Abd El-Razek, H. A. Bassioni, and A. M. Mobarak, "Causes of delay in building construction projects in Egypt," Journal of Construction Engineering and Management, vol. 134, no. 11, pp. 831-841, 2008.

[19] N. Azhar, R. U. Farooqui, and S. M. Ahmed, "Cost overrun factors in construction industry of Pakistan," in Proceedings of the first international Conference on construction in developing countries (ICCIDC-I), Advancing and integrating 
construction education, Research \& Practice, Karachi, Pakistan, August 2008.

[20] S. Durdyev and S. Ismail, "On-site construction productivity in Malaysian infrastructure projects," Structural Survey, vol. 34, no. 4-5, pp. 446-462, 2016.

[21] S. G. Naoum, "Factors influencing labor productivity on construction sites," International Journal of Productivity and Performance Management, vol. 65, no. 3, pp. 401-421, 2016.

[22] S. Emmitt and C. Gorse, Communication in Construction Teams, Routledge, London, UK, 2006.

[23] X. Meng, "The effect of relationship management on project performance in construction," International Journal of Project Management, vol. 30, no. 2, pp. 188-198, 2012.

[24] S. D. Lavender, Management for the Construction Industry, Routledge, London, UK, 2014.

[25] A. Kazaz and S. Ulubeyli, "Drivers of productivity among construction workers: a study in a developing country," Building and Environment, vol. 42, no. 5, pp. 2132-2140, 2007.

[26] A. M. Jarkas and M. Radosavljevic, "Motivational factors impacting the productivity of construction master craftsmen in Kuwait," Journal of Management in Engineering, vol. 29, no. 4, pp. 446-454, 2012.

[27] N. Jaffar, A. H. A. Tharim, and M. N. Shuib, "Factors of conflict in construction industry: a literature review," Procedia Engineering, vol. 20, pp. 193-202, 2011.

[28] I. M. Shohet and A. Laufer, "What does the construction foreman do?" Construction Management and Economics, vol. 9, no. 6, pp. 565-576, 1991.

[29] M. A. Islam and M. M. R. K. Khadem, "Productivity determinants in Oman construction industry," International Journal of Productivity and Quality Management, vol. 12, no. 4 , pp. 426-448, 2013.

[30] A. M. Jarkas and C. G. Bitar, "Factors affecting construction labor productivity in Kuwait," Journal of Construction Engineering and Management, vol. 138, no. 7, pp. 811-820, 2011.

[31] R. F. Aziz and S. M. Hafez, "Applying lean thinking in construction and performance improvement," Alexandria Engineering Journal, vol. 52, no. 4, pp. 679-695, 2013.

[32] A. Mills, "A systematic approach to risk management for construction," Structural Survey, vol. 19, no. 5, pp. 245-252, 2001.

[33] S. Q. Wang, M. F. Dulaimi, and M. Y. Aguria, "Risk management framework for construction projects in developing countries," Construction Management and Economics, vol. 22, no. 3, pp. 237-252, 2004.

[34] S. P. Singh, Factors Affecting the Productivity of Construction Operations in the United Arab Emirates, Heriot-Watt University, Edinburgh, Scotland, 2010.

[35] S. Alwi, "Factors influencing construction productivity in the Indonsesian context," in Proceedings of the 5th EASTS Conference, Fukuoka, Japan, October 2003.

[36] P. Ghoddousi and M. R. Hosseini, "A survey of the factors affecting the productivity of construction projects in Iran," Technological and Economic Development of Economy, vol. 18, no. 1, pp. 99-116, 2012.

[37] H. R. Thomas, M. J. Horman, R. E. Minchin Jr., and D. Chen, "Improving labor flow reliability for better productivity as lean construction principle," Journal of Construction Engineering and Management, vol. 129, no. 3, pp. 251-261, 2003.

[38] M. Abrey and J. J. Smallwood, "The effects of unsatisfactory working conditions on productivity in the construction industry," Procedia Engineering, vol. 85, pp. 3-9, 2014.
[39] A. S. Hanna and D. G. Heale, "Factors affecting construction productivity: newfoundland versus rest of Canada," Canadian Journal of Civil Engineering, vol. 21, no. 4, pp. 663-673, 1994.

[40] E. D. Wagner and A. P. Derryberry, "Return on investment (ROI) in action: techniques for "selling" interactive technologies," Educational Technology, vol. 38, no. 4, pp. 22-27, 1998.

[41] D. Samson and M. Terziovski, "The relationship between total quality management practices and operational performance," Journal of Operations Management, vol. 17, no. 4, pp. 393-409, 1999.

[42] A. Jafari and P. E. D. Love, "Quality costs in construction: case of qom monorail project in Iran," Journal of Construction Engineering and Management, vol. 139, no. 9, pp. 1244-1249, 2013.

[43] A. L. Jepsen and P. Eskerod, "Stakeholder analysis in projects: challenges in using current guidelines in the real world," International Journal of Project Management, vol. 27, no. 4, pp. 335-343, 2009.

[44] H. Song, K. Yu, and S. Zhang, "Green procurement, stakeholder satisfaction and operational performance," The International Journal of Logistics Management, vol. 28, no. 4, pp. 1054-1077, 2017.

[45] S. H. Nam, D. Y. Lee, B. H. Cho, and K. R. Kim, "Integrated management software for factory production of modular buildings," Advances in Civil Engineering, vol. 2019, Article ID 7693459, 10 pages, 2019.

[46] E. Agazzi, "From technique to technology," Techné: Research in Philosophy and Technology, vol. 4, no. 2, pp. 80-85, 1998.

[47] A. Isman, "Technology and technique: an educational perspective," Turkish Online Journal of Educational TechnologyTOJET, vol. 11, no. 2, pp. 207-213, 2012.

[48] P. Nguyen and R. Akhavian, "Synergistic effect of integrated project delivery, lean construction, and building information modeling on project performance measures: a quantitative and qualitative analysis," Advances in Civil Engineering, vol. 2019, Article ID 1267048, 9 pages, 2019.

[49] A. Gunasekaran and P. Cecille, "Implementation of productivity improvement strategies in a small company," Technovation, vol. 18, no. 5, pp. 311-320, 1998.

[50] S. A. Ismail, S. Bandi, and Z. N. Maaz, "An appraisal into the potential application of big data in the construction industry," International Journal of Built Environment and Sustainability, vol. 5, no. 2, pp. 145-154, 2018.

[51] M. Bilal, L. O. Oyedele, O. O. Akinade et al., "Big data architecture for construction waste analytics (CWA): a conceptual framework," Journal of Building Engineering, vol. 6, pp. 144-156, 2016.

[52] J. Shrestha, Big Data, Predictive Analytics, and Data Visualization in the Construction Engineering. CCEE Graduate Student Research Showcase and Poster Competition, Iowa State University, Ames, Iowa, 2013, http://works.bepress. com/joseph_shrestha/2.

[53] I. Motawa, "Big Data for Smart Operations and Maintenance of Buildings," in Proceedings of the 15th International Operation and Maintenance Conference, Beirut, Lebanon, October 2017

[54] R. Eadie, M. Browne, H. Odeyinka, C. McKeown, and S. McNiff, "BIM implementation throughout the UK construction project lifecycle: an analysis," Automation in Construction, vol. 36, pp. 145-151, 2013.

[55] P. Li, S. Zheng, H. Si, and K. Xu, "Critical challenges for BIM adoption in small and medium-sized enterprises: evidence 
from China," Advances in Civil Engineering, vol. 2019, Article ID 9482350, 14 pages, 2019.

[56] S. Azhar, "Building information modeling (BIM): trends, benefits, risks, and challenges for the AEC industry," Leadership and Management in Engineering, vol. 11, no. 3, pp. 241-252, 2011.

[57] R. Azuma, Y. Baillot, R. Behringer, S. Feiner, S. Julier, and B. MacIntyre, "Recent advances in augmented reality," IEEE Computer Graphics and Applications, vol. 21, no. 6, pp. 3447, 2001.

[58] Y. Jiao, S. Zhang, Y. Li, Y. Wang, and B. Yang, "Towards cloud augmented reality for construction application by BIM and SNS integration," Automation in Construction, vol. 33, pp. 37-47, 2013.

[59] E. Olshannikova, A. Ometov, Y. Koucheryavy, and T. Olsson, "Visualizing Big Data with augmented and virtual reality: challenges and research agenda," Journal of Big Data, vol. 2, no. 1, 2015.

[60] I. A. Khalek, J. M. Chalhoub, and S. K. Ayer, "Augmented reality for identifying maintainability concerns during design," Advances in Civil Engineering, vol. 2019, Article ID 8547928, 12 pages, 2019.

[61] M. Zyda, "From visual simulation to virtual reality to games," Computer, vol. 38, no. 9, pp. 25-32, 2005.

[62] R. Sacks, A. Perlman, and R. Barak, "Construction safety training using immersive virtual reality," Construction Management and Economics, vol. 31, no. 9, pp. 1005-1017, 2013.

[63] J. I. Messner, S. C. Yerrapathruni, A. J. Baratta, and V. E. Whisker, "Using virtual reality to improve construction engineering education," The American Society for Engineering Education Annual Conference \& Exposition, vol. 1121, 2003.

[64] M. Crosby, P. Pattanayak, S. Verma, and V. Kalyanaraman, "Blockchain technology: beyond bitcoin," Applied Innovation, vol. 2, pp. 6-10, 2016.

[65] I. Belle, "The architecture, engineering and construction industry and blockchain technology," in Proceedings of National Conference on Digital Technologies in Architectural Education and DADA, pp. 279-284, Nanjing, China, 2017.

[66] Ž. Turk and R. Klinc, "Potentials of blockchain technology for construction management," Procedia Engineering, vol. 196, pp. 638-645, 2017.

[67] R. Zheng, J. Jiang, X. Hao, W. Ren, F. Xiong, and Y. Ren, "bcBIM: a blockchain-based big data model for BIM modification audit and provenance in mobile cloud," Advances in Civil Engineering, vol. 2019, Article ID 5349538, 13 pages, 2019.

[68] M. Pilkington, Blockchain Technology: Principles and Applications, Research Handbook on Digital Transformations, Edward Elgar Publishing, Cheltenham, UK, 2016.

[69] S. El-Omari and O. Moselhi, "Integrating 3D laser scanning and photogrammetry for progress measurement of construction work," Automation in Construction, vol. 18, no. 1, pp. 1-9, 2008.

[70] J. D. Goedert and P. Meadati, "Integrating construction process documentation into building information modeling," Journal of Construction Engineering and Management, vol. 134, no. 7, pp. 509-516, 2008.

[71] S. El-Omari and O. Moselhi, "Integrating automated data acquisition technologies for progress reporting of construction projects," Automation in Construction, vol. 20, no. 6, pp. 699-705, 2011.
[72] Y. Y. Su, Y. M. A. Hashash, and L. Y. Liu, "Integration of construction as-built data via laser scanning with geotechnical monitoring of urban excavation," Journal of Construction Engineering and Management, vol. 132, no. 12, pp. 1234-1241, 2006.

[73] T. Randall, "Construction engineering requirements for integrating laser scanning technology and building information modeling," Journal of Construction Engineering and Management, vol. 137, no. 10, pp. 797-805, 2011.

[74] S. H. Chen, A. J. Jakeman, and J. P. Norton, "Artificial intelligence techniques: an introduction to their use for modelling environmental systems," Mathematics and Computers in Simulation, vol. 78, no. 2-3, pp. 379-400, 2008.

[75] T. Dede, M. Kankal, A. R. Vosoughi, M. Grzywi'nski, and M. Kripka, "Artificial intelligence applications in civil engineering," Advances in Civil Engineering, vol. 2019, Article ID 8384523, 3 pages, 2019.

[76] D. S. Nau, "Artificial intelligence and automation," in Springer Handbook of Automation, S. Nof, Ed., Springer, Berlin, Germany, 2009.

[77] C. J. Anumba, O. O. Ugwu, L. Newnham, and A. Thorpe, "Collaborative design of structures using intelligent agents," Automation in Construction, vol. 11, no. 1, pp. 89-103, 2002.

[78] S. Bose, How Artificial Intelligence Can Increase Your Business Productivity, Digitalist Magazine, Alexandria, VA, USA, 2018, https://www.digitalistmag.com/future-ofwork/2018/03/19/how-artificial-intelligence-can-increaseyour-business-productivity-05978998.

[79] B. Jose, F. Steffen, P. Matthew, and J. R. Maria, "Artificial Intelligence: Construction Technology's Next Frontier, McKinsy and Company, Philadelphia, PA, USA, 2018, https://www.mckinsey.com/industries/capital-projects-andinfrastructure/our-insights/artificial-intelligence-constructiontechnologys-next-frontier.

[80] N. Blismas and R. Wakefield, "Drivers, constraints and the future of offsite manufacture in Australia," Construction Innovation, vol. 9, no. 1, pp. 72-83, 2009.

[81] P. Sabet and H. Y. Chong, "Interactions between building information modelling and off-site manufacturing for productivity improvement," International Journal of Managing Projects in Business, vol. 12, 2019.

[82] SBEnrc, Accelerating the Mainstreaming of Building Manufacture in Australia, Sustainable Built Environment National Research Center, Perth, Australia, 2017.

[83] M. P. Groover, Fundamentals of Modern Manufacturing: Materials, Processes, and Systems, John Wiley \& Sons, New Jersy, NY, USA, 2014, https://futureingscientist.files. wordpress.com/2014/01/copy-of-fundamentals-of-modernmanufacturing-4th-edition-by-mikell-p-groover.pdf.

[84] J. D. Lee and K. A. See, "Trust in automation: designing for appropriate reliance," Human Factors: The Journal of the Human Factors and Ergonomics Society, vol. 46, no. 1, pp. 50-80, 2004.

[85] J. See, "Automation in the prefab and modular construction industry," in Proceedings of the the 26th Symposium on Construction Robotics ISARC, Austin, TX, USA, June 2009.

[86] M. Hannula, "Total productivity measurement based on partial productivity ratios," International Journal of Production Economics, vol. 78, no. 1, pp. 57-67, 2002.

[87] A. L. Huang, R. E. Chapman, and D. T. Butry, Metrics and Tools for Measuring Construction Productivity: Technical and Empirical Considerations, U.S. Department of Commerce National Institute of Standards and Technology, 
Gaithersburg, MD, USA, 2009, https://ws680.nist.gov/ publication/get_pdf.cfm?pub_id=903603.

[88] S. P. Dozzi and S. M. AbouRizk, Productivity in Construction, National Research Council, Ottawa, Canada, 1993.

[89] A. Hasan, B. Baroudi, A. Elmualim, and R. Rameezdeen, "Factors affecting construction productivity: a 30 year systematic review," Engineering, Construction and Architectural Management, vol. 25, no. 7, pp. 916-937, 2018.

[90] R. F. Cox, R. R. A. Issa, and D. Ahrens, "Management's perception of key performance indicators for construction," Journal of Construction Engineering and Management, vol. 129, no. 2, pp. 142-151, 2003.

[91] S. Golnaraghi, Z. Zangenehmadar, O. Moselhi, and S. Alkass, "Application of artificial neural network(s) in predicting formwork labour productivity," Advances in Civil Engineering, vol. 2019, Article ID 5972620, 11 pages, 2019.

[92] H. Elnaas, K. Gidado, and P. Ashton, "Factors and drivers effecting the decision of using off-site manufacturing (OSM) systems in house building industry," Journal of Engineering, Project, and Production Management, vol. 4, no. 1, pp. 51-58, 2014.

[93] J. Lessing, L. Stehn, and A. Ekholm, "Industrialized housing: definition and categorization of the concept," in Proceedings of the Annual Conference of the International Group for Lean Construction, pp. 471-480, Sydney, Australia, July 2005.

[94] C. L. Pasquire and G. E. Connolly, "Leaner construction through off-site manufacturing," in Proceedings of the IGLC10, Gramado, Brazil, August 2002.

[95] S. Durdyev and S. Ismail, "Offsite manufacturing in the construction industry for productivity improvement," Engineering Management Journal, vol. 31, no. 1, pp. 35-46, 2019.

[96] L. Ding, Y. Zhou, and B. Akinci, "Building Information Modeling (BIM) application framework: the process of expanding from $3 \mathrm{D}$ to computable $\mathrm{nD}$," Automation in Construction, vol. 46, pp. 82-93, 2014.

[97] J. H. Kang, S. D. Anderson, and M. J. Clayton, "Empirical study on the merit of web-based $4 \mathrm{D}$ visualization in collaborative construction planning and scheduling," Journal of Construction Engineering and Management, vol. 133, no. 6, pp. 447-461, 2007.

[98] J. Li, L. Hou, X. Wang et al., “A project-based quantification of BIM benefits," International Journal of Advanced Robotic Systems, vol. 11, no. 8, 2014.

[99] N. Lee, T. Salama, and G. Wang, "Building information modeling for quality management in infrastructure construction projects," in Proceedings of the Computing in Civil and Building Engineering, pp. 65-72, Orlando, FL, USA, June 2014.

[100] L. Chen and H. Luo, "A BIM-based construction quality management model and its applications," Automation in Construction, vol. 46, pp. 64-73, 2014.

[101] S. Khoshnava, A. Ahankoob, C. Preece, and R. Rostami, "Application of BIM in construction safety," in Proceedings of the Management in Construction Research Association (MiCRA), Kuala Lumpur, Malaysia, December 2012.

[102] K. Sulankivi, K. Kähkönen, T. Mäkelä, and M. Kiviniemi, "4D-BIM for construction safety planning," in Proceedings of W099-Special Track 18th CIB World Building Congress, Salford, UK, May 2010.

[103] X. Wang and P. E. Love, "BIM+ AR: onsite information sharing and communication via advanced visualization," in Proceedings of the Computer Supported Cooperative Work in Design (CSCWD), Wuhan, China, May 2012.
[104] P. Smith, "BIM implementation—global strategies," Procedia Engineering, vol. 85, pp. 482-492, 2014.

[105] X. Li, W. Yi, H.-L. Chi, X. Wang, and A. P. C. Chan, "A critical review of virtual and augmented reality (VR/AR) applications in construction safety," Automation in Construction, vol. 86, pp. 150-162, 2018.

[106] J. Wong, X. Wang, H. Li, and G. Chan, "A review of cloudbased BIM technology in the construction sector," Journal of Information Technology in Construction, vol. 19, pp. 281-291, 2014.

[107] A. Behzadi, "Using augmented and virtual reality technology in the construction industry," American Journal of Engineering Research, vol. 5, no. 12, pp. 350-353, 2016.

[108] W. Shen, Q. Hao, H. Mak et al., "Systems integration and collaboration in architecture, engineering, construction, and facilities management: a review," Advanced Engineering Informatics, vol. 24, no. 2, pp. 196-207, 2010.

[109] Z. Pan, A. D. Cheok, H. Yang, J. Zhu, and J. Shi, "Virtual reality and mixed reality for virtual learning environments," Computers \& Graphics, vol. 30, no. 1, pp. 20-28, 2006.

[110] D. Zhao and J. Lucas, "Virtual reality simulation for construction safety promotion," International Journal of Injury Control and Safety Promotion, vol. 22, no. 1, pp. 57-67, 2015.

[111] Y. Fang, J. Teizer, and E. Marks, "A framework for developing an as-built virtual environment to advance training of crane operators," in Proceedings of the Construction Research Congress 2014, Atlanta, Georgiam, May 2014.

[112] R. Oudshoorn, "Utilizing virtual reality in a dynamic stakeholder process," Master thesis, Technical University, Delft, Netherlands, 2018.

[113] D. Gleason, "Laser scanning for an integrated BIM," in Proceedings of the Lake Constance 5D-Conference, Constanza, Dominican Republic, October 2013.

[114] D. Huber, B. Akinci, P. Tang, A. Adan, B. Okorn, and X. Xiong, "Using Laser Scanners for Modeling and Analysis in Architecture, Engineering, and Construction," in Proceedings of the 44th Annual Conference on Information Sciences and Systems (CISS), Princeton, NJ, USA, March 2010.

[115] D. Tapscott and A. Tapscott, "How blockchain will change organizations," MIT Sloan Management Review, vol. 58, no. 2, pp. 10-13, 2017.

[116] M. Kassem, J. Lia, and D. Greenwood, "Blockchain in the built environment: analysing current applications and developing an emergent framework," in Proceedings of the Creative Construction Conference, Ljubljana, Slovenia, June 2018, http://nrl.northumbria.ac.uk/id/eprint/34633.

[117] W. Lu, X. Chen, Y. Peng, and L. Shen, "Benchmarking construction waste management performance using big data," Resources, Conservation and Recycling, vol. 105, pp. 49-58, 2015.

[118] J. Brandenburger, V. Colla, G. Nastasi, F. Ferro, C. Schirm, and J. Melcher, "Big data solution for quality monitoring and improvement on flat steel Production: the research leading to these results has received funding from the European community's research fund for coal and steel (RFCS) under grant agreement $n^{\circ}$ RFSR-CT-2012-00040," IFAC-PapersOnLine, vol. 49, no. 20, pp. 55-60, 2016.

[119] S. F. Wamba, S. Akter, and M. De Bourmont, "Quality dominant logic in big data analytics and firm performance," Business Process Management Journal, vol. 25, no. 3, pp. 512-532, 2019.

[120] A. Ø. Sørensen, N. Olsson, and A. D. Landmark, Big Data in Construction Management Research, vol. 3, pp. 405-416, 
Tampere University of Technology, Tampere, Finland, 2016, http://hdl.handle.net/11250/2396557.

[121] C. Balaguer and M. Abderrahim, Trends in Robotics and Automation in Construction, University Carlos III, Madrid, Spain, 2008, http://www.intechopen.com/books/robotics\% 20and\%20automation\%20in\%20construction/trends\%20in\% 20robotics\%20and\%20automation\%20in\%20construction.

[122] T. Hegazy, "Optimization of resource allocation and leveling using genetic algorithms," Journal of Construction Engineering and Management, vol. 125, no. 3, pp. 167-175, 1999.

[123] A. O. Elfaki, S. Alatawi, and E. Abushandi, "Using intelligent techniques in construction project cost estimation: 10-year survey," Advances in Civil Engineering, vol. 2014, Article ID 107926, 11 pages, 2014, http://dx.doi.org/10.1155/2014/107926.

[124] J. Peleska, "Test automation for safety-critical systems: industrial application and future developments," in Proceedings of the International Symposium of Formal Methods Europe, vol. 1051, Newcastle, UK, July 2005.

[125] P. X. W. Zou, G. Zhang, and J. Wang, "Understanding the key risks in construction projects in China," International Journal of Project Management, vol. 25, no. 6, pp. 601-614, 2007.

[126] P. Meadati, "BIM Extension into Later Stages of Project Life Cycle," in Proceedings of the Associated Schools of Construction 45th Annual International Conference, Southern Polytechnic State University, Marietta, GA, USA, April 2009.

[127] Y. Ji, S. Chang, Y. Qi, Y. Li, H. X. Li, and K. Qi, “A BIM-based study on the comprehensive benefit analysis for prefabricated building projects in China," Advances in Civil Engineering, vol. 2019, Article ID 3720191, 13 pages, 2019.

[128] A. T. Gurmu and C. S. Ongkowijoyo, "Predicting construction labor productivity based on implementation levels of human resource management practices," Journal of Construction Engineering and Management, vol. 146, no. 3, 2020. 